\title{
Activin-A as an Intraovarian Modulator: Actions, Localization, and Regulation of the Intact Dimer in Human Ovarian Cells
}

\author{
Jaron Rabinovici, Susan J. Spencer, Nicola Doldi, Paul C. Goldsmith, Ralph Schwall, ${ }^{\text {and Robert B. Jaffe }}$ \\ Reproductive Endocrinology Center, Department of Obstetrics, Gynecology and Reproductive Sciences, University of California, \\ San Francisco, San Francisco, California 94143; and ${ }^{\ddagger}$ Genentech, Inc., South San Francisco, California 94080
}

\begin{abstract}
The actions, localization, and regulation of activin in the human ovary are unknown. Therefore, the aims of this study were (a) to define the effects of recombinant activin-A and its structural homologue, inhibin- $\mathrm{A}$, on mitogenesis and steroidogenesis (progesterone secretion and aromatase activity) in human preovulatory follicular cells; (b) to localize the activin-A dimer in the human ovary by immunohistochemistry; and (c) to examine regulation of intracellular activin-A production in cultured human follicular cells. In addition to stimulating mitogenic activity, activin-A causes a dose- and time-dependent inhibition of basal and gonadotropin-stimulated progesterone secretion and aromatase activity in human luteinizing follicular cells on day 2 and day 4 of culture. Inhibin-A exerts no effects on mitogenesis, basal or gonadotropin-stimulated progesterone secretion and aromatase activity, and does not alter effects observed with activin-A alone. Immunostaining for dimeric activin-A occurs in granulosa and cumulus cells of human ovarian follicles and in granulosa-lutein cells of the human corpus luteum. CAMP, and to a lesser degree human chorionic gonadotropin and folliclestimulating hormone, but not inhibin-A, activin-A, or phorbol 12-myristate 13-acetate, increased the immunostaining for activin-A in cultured granulosa cells. These results indicate that activin-A may function as an autocrine or paracrine regulator of follicular function in the human ovary. (J. Clin. Invest. 1992. 89:1528-1536.) Key words: ovary • activin $\bullet$ inhibin $\bullet$ sex steroids
\end{abstract}

\section{Introduction}

Intragonadal peptides, in addition to the pituitary gonadotropins follicle-stimulating hormone (FSH) and luteinizing hormone, play a major role in the control of ovarian function during fetal and postnatal life $(1,2)$. The gonadal peptides activin and inhibin can indirectly affect ovarian function through modulation of pituitary FSH release (3). However, recent evidence in rat and bovine ovarian cells indicates that activin and

Address correspondence and reprint requests to Robert B. Jaffe, M. D., Reproductive Endocrinology Center, Department of Obstetrics, Gynecology and Reproductive Sciences, University of California, San Francisco, San Francisco, CA 94143-0132.

Received for publication 24 May 1991 and in revised form 8 October 1991.

1. Abbreviations used in this paper: $\mathrm{FSH}$, follicle-stimulating hormone; hCG, human chorionic gonadotropin; TGF- $\beta$, transforming growth factor $-\beta$.

J. Clin. Invest.

(c) The American Society for Clinical Investigation, Inc.

0021-9738/92/05/1528/09 \$2.00

Volume 89, May 1992, 1528-1536 inhibin also may directly regulate intraovarian processes (411). These direct effects of activin and inhibin on ovarian function appear to depend upon species and experimental conditions. We reported recently that activin-A increases proliferation of cultured human preovulatory luteinizing ovarian follicular cells in a dose- and time-dependent fashion (12). However, little is known about the effects of activin on steroidogenesis or the effects of activin's structural homologue, inhibin, on proliferation and steroidogenesis of human ovarian cells.

The structurally related activin and inhibin dimers were first isolated from ovarian follicular fluid (3). Activins are composed of two homologous but distinct $\beta$-subunits, $\beta \mathrm{A}$ and $\beta \mathrm{B}$ (activin-A $[\beta \mathrm{A} / \beta \mathrm{A}]$, activin- $\mathrm{AB}[\beta \mathrm{A} / \beta \mathrm{B}]$, and activin- $\mathrm{B}[\beta \mathrm{B} /$ $\beta B])(3,13)$ and inhibins are composed of an $\alpha$-subunit linked to either of the two $\beta$-subunits (inhibin-A $[\alpha / \beta \mathrm{A}]$ and inhibin-B $[\alpha / \beta \mathrm{B}])$ by disulfide bridges $(3,13)$. Only the intact activin and inhibin dimers exhibit biological activity. Due to the lack of antibodies specific for the activin and inhibin dimers, localization of these dimers in the ovary previously was deduced from immunostaining for the individual subunits, or from in situ and Northern blot hybridizations for the subunit mRNAs. Using these techniques, it was found that the subunits of activins and inhibins and their mRNAs are expressed during the menstrual cycle in ovarian follicular cells in a variety of species (13-19). However, the detection of the subunits may reflect the presence of the biologically active dimers of either activin or inhibin or free monomeric precursors. Thus, definitive evidence for the cellular location of activin dimers in the ovary and their regulation has been lacking.

In this study, we determined the steroidogenic and mitogenic effects of recombinant human activin-A and inhibin-A on cultured human luteinizing ovarian follicular cells. We also examined the cellular localization of immunoreactive dimeric activin-A in human ovarian cells by immunocytochemistry, using a recently prepared monoclonal antibody directed against the intact, human activin-A dimer. Finally, using the same immunocytochemical technique, we examined which trophic agents regulate cellular accumulation of immunoreactive dimeric activin in dispersed cultured human luteinizing ovarian follicular cells.

\section{Methods}

Materials. Medium 199 supplemented with Earle's balanced salt solution, glutamine, gentamicin, fetal bovine serum, and saline with $0.05 \%$ trypsin-verseine were obtained from the Cell Culture Facility, University of California, San Francisco (UCSF). Collagenase-dispase was obtained from Boehringer-Mannheim GmbH (Mannheim, FRG) and Ficoll-Paque from Pharmacia Fine Chemicals (Piscataway, NJ). Tissue culture dishes were from Falcon Labware (Oxnard, CA). Recombinant human activin-A, recombinant human inhibin-A, recombinant 
human transforming growth factor- $\beta$, and monoclonal antibodies against intact activin-A were provided by Genentech (South San Francisco, CA).

Cell culture. Human luteinizing granulosa cells were obtained by follicular aspiration from regularly menstruating women undergoing ovum retrieval for in vitro fertilization performed because of tubal obstruction. Follicular development had been stimulated by human menopausal gonadotropins (Serono Laboratories, Inc., Randolph, MA) in the presence of a GnRH analogue (Lupron; TAP Pharmaceuticals, North Chicago, IL) until adequate response was achieved. The criteria for adequate response included three follicles $>14 \mathrm{~mm}$ with at least one follicle $>16 \mathrm{~mm}$ and an estradiol concentration $>600 \mathrm{pg} / \mathrm{ml}$, which was increasing daily. Final maturation of the oocytes was effected with 10,000 IU human chorionic gonadotropin (hCG; Serono Laboratories). Retrieval was accomplished $35 \mathrm{~h}$ after the injection. Granulosa cells aspirated from follicles $>15 \mathrm{~mm}$ in diameter were used in the study. Cells were washed twice with medium M-199. Granulosa cells and red blood cells were transferred to a $12-\mathrm{ml}$ tube containing 3.5 $\mathrm{ml}$ Ficoll-Paque and separated by centrifugation at $600 \mathrm{~g}$ for $5 \mathrm{~min}$. Granulosa cells formed a thin layer between the upper phase (culture medium) and lower phase (Ficoll-Paque), while red blood cells settled to the bottom of the tube. Granulosa cells were dispersed by gentle shaking at $37^{\circ} \mathrm{C}$ for $30 \mathrm{~min}$ in $5 \mathrm{ml}$ culture medium containing $0.1 \%$ collagenase-dispase and $20 \mathrm{mg} \mathrm{DNase} / \mathrm{ml}$. The dispersed cells were washed in culture medium, counted, and plated at a density of 10,000 50,000 cells/well in 24 multiwell plates. Cells were cultured at $37^{\circ} \mathrm{C}$ in $95 \%$ air, $5 \% \mathrm{CO}_{2}$ with or without recombinant human activin-A or recombinant human inhibin-A (1-300 $\mathrm{ng} / \mathrm{ml})$. Medium was changed every other day. Cell number in each well was determined with a Coulter Counter (Coulter Corp., Hialeah, FL) after trypsinization. For immunocytochemical studies, luteinizing follicular cells were cultured on 8-well Lab-Tek plates (Nunc Inc., Naperville, IL) at a density of $2,000-5,000$ cells per well for $48-96 \mathrm{~h}$.

The culture medium for proliferation experiments consisted of medium M-199 containing 10\% fetal bovine serum, $2 \mathrm{mM}$ glutamine, and $50 \mathrm{mg} / \mathrm{ml}$ gentamicin. Cell number was assessed by Coulter Counter on days 4-6 of culture. Culture medium for determination of progesterone secretion consisted of medium M-199 containing $0.1 \%$ human serum albumin (Baxter Healthcare Corp., Glendale, CA), $2 \mathrm{mM}$ glutamine, and $50 \mathrm{mg} / \mathrm{ml}$ gentamicin. The spent medium was frozen at $-20^{\circ} \mathrm{C}$ until assayed. Progesterone was measured directly from the medium by radioimmunoassay as described previously from these laboratories (20). For the assessment of aromatase activity, $10^{-6} \mathrm{M}$ androstenedione was added as precursor to the culture medium and the spent medium was assayed for $17-\beta$ estradiol by RIA as described previously (21, 22).

Tissue preparation. Human ovaries were obtained immediately after oophorectomy performed under general anesthesia in reproductive age women. Human tissue was removed for nonovarian disease and used in accordance with guidelines of the Human and Environmental Protection Committee, UCSF.

Monoclonal antibodies and absorption control. Monoclonal antibodies specific for activin-A were produced using the mutant hypogonadal mouse (Jackson ImmunoResearch Laboratories, Inc., West Grove, PA). Mice were hyperimmunized in the hind foot pad with $5 \mu \mathrm{g}$ doses of purified recombinant activin-A. Inguinal and popliteal node lymphocytes were fused with a mouse myeloma cell line, as described previously (23). Production of antibodies by the resulting hybridomas was assessed by solid-phase ELISA. Specificity was checked by a subsequent solid-phase ELISA using inhibin-A as the coat antigen. In brief, each well of a 96-well plate was coated overnight at $4^{\circ} \mathrm{C}$ with $100 \mathrm{ng}$ of either recombinant activin-A or recombinant inhibin-A in $100 \mu$ l PBS. The plate was washed once with PBS, $0.05 \%$ Tween-20 and then blocked with PBS, $0.5 \%$ BSA for $1 \mathrm{~h}$ at room temperature. The antibody was serially diluted twofold in blocking buffer, then $100-\mu 1$ aliquots were transferred to the plate. After a 2-h incubation at room temperature, the plate was washed six times with PBS, $0.05 \%$ Tween20 , and then $100 \mu \mathrm{l}$ of a $1: 1,000$ dilution of horseradish peroxidase anti-mouse IgG was added to each well. After an additional 2-h incubation, the plate was again washed six times. Bound horseradish peroxidase was detected by standard development with $o$-phenylenediamine and hydrogen peroxide, followed by addition of sulfuric acid to stop the reaction. Absorbance was measured at $490 \mathrm{~nm}$ with subtraction of a reference absorbance at $405 \mathrm{~nm}$ (Fig. 1). The specificity was further characterized by testing immunoprecipitation of metabolically labeled activin-A and inhibin-A, produced as described previously (24). The antibody used in the present studies did not cross-react with inhibin in either of these methods.

Specificity of the monoclonal antibody to intact activin-A was also tested by Western blot. $\beta$ A monomer was generated by reducing intact, dimeric activin-A with $5 \% \beta$-mercaptoethanol at $55^{\circ} \mathrm{C}$ for $60 \mathrm{~min}$. Monoclonal antibody reacted with intact activin-A dimer, showing a single band at 24,000 but there was no detectable band in the lane containing the monomeric subunit. Thus, no cross-reactivity was observed between the monoclonal antibody for activin-A and either inhibin-A or $\beta \mathrm{A}$ monomer.

To test for specificity of the immunohistochemical staining, we initially attempted to absorb the antibody with activin-A in solution. However, activin has limited solubility at neutral $\mathrm{pH}$ and we were not able to achieve adequate concentrations. Therefore, we used a solidphase absorption. Activin-A was coated onto a 96 -well plate $(2 \mu \mathrm{g} /$ well $)$ overnight at $4^{\circ} \mathrm{C}$. All subsequent incubations were performed at room temperature. The plate was blocked with $5 \%$ BSA for $1 \mathrm{~h}$. The antibody was diluted to $10 \mu \mathrm{g} / \mathrm{ml}$ and $0.1-\mathrm{ml}$ aliquots were added to the top 12 wells of the plate. Similar aliquots were added to a plate that had been coated with the activin-A diluent as a control. At 1-h intervals the aliquots were transferred to the next row down. After the material had reached the bottom row, it was collected and pooled.

Histology and immunohistochemistry. For immunocytochemistry, the ovaries and cultured cells were immersion fixed for at least $48 \mathrm{~h}$ in phosphate-buffered $4 \%$ paraformaldehyde. The whole tissue blocks were embedded in paraffin, and serial sections $(10-\mu \mathrm{m}$ thick) were mounted two or three per gelatin-subbed microscope slide. Slides were deparaffinized in graded ethanols and hydrated to $0.1 \mathrm{M}$ Tris-saline buffer, $\mathrm{pH} 7.4$, immediately before staining.

Sections and fixed cells were pretreated with $1 \% \mathrm{H}_{2} \mathrm{O}_{2}$ for $20 \mathrm{~min}$. The tissue was incubated for $1-12 \mathrm{~h}$ with a monoclonal antibody raised against the activin-A dimer at a concentration of $2-10 \mu \mathrm{g} / \mathrm{ml}$. Immunohistochemical staining was completed using the Vectastain Elite $A B C$ Kit (Vector Lab, Inc., Burlingame, CA) with diaminobenzidine as the chromogen. No immunopositive staining was observed in control sections reacted either with absorbed antiserum or with normal mouse serum (1:500) in place of the primary antiserum used. Tissue sections were then dehydrated in graded ethanols, cleared in xylene, and mounted with Protexx (Scientific Products, McGraw Park, IL). Photographs were taken with Kodak Technical Pan film (ASA 100).

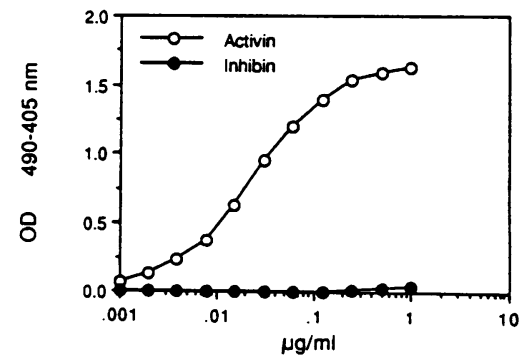

Figure 1. Specificity of activin-A monoclonal antibody. The ability of activin-A monoclonal antibody to bind activin-A (open circles) or inhibin-A (closed circles) was determined by coating the wells of a 96-well plate with activin-A or inhibin-A, followed by addition of the monoclonal antibody at the concentrations indicated on the $x$ axis. Bound antibody was then detected using an HRP anti-mouse IgG conjugate. Absorbance was measured at $490 \mathrm{~nm}$ after subtraction at the reference wavelength of $405 \mathrm{~nm}$. Each point is the mean of duplicates which varied $<5 \%$. 
Statistical analysis. Treatments were performed in triplicate and values shown are from $\geq 4$ experiments. Statistical comparisons between groups were made either by paired $t$ test or by one-way analysis of variance and Fisher protected least significant difference (PLSD) or Scheffe $F$ test as posttests. Progesterone and aromatase activity levels of treated wells are expressed as percent levels of untreated control wells (designated at $100 \%$ ). Values are expressed as mean \pm SEM. Signifcance was assumed by $P \leq 0.05$.

\section{Results}

Effects of activin-A on steroidogenesis. Activin-A significantly decreased basal progesterone secretion on days 2 and 4 of culture. The decrease was dose- and time-dependent (Figs. 2 and 3). Maximal inhibition of basal progesterone secretion by $95 \pm 2 \%$ (mean $\pm \mathrm{SE}$ ) was seen on day 4 of culture. Concomitant exposure to hCG and activin-A decreased hCG-stimulated progesterone secretion in a dose-dependent manner (Fig. 3). Addition of $600 \mathrm{IU} /$ liter of hCG increased basal progesterone secretion significantly (400\% of control) (Fig. 4).

Activin-A inhibited both basal (maximal decrease of $32 \pm 10 \%$ on day 2 and $81 \pm 20 \%$ on day 4) (Fig. 5) as well as FSH-stimulated (600 IU/liter) aromatase activity (Fig. 6). This inhibition was in contrast to the observed stimulatory effects on FSH-stimulated aromatase activity of transforming growth factor- $\beta$ (TGF- $\beta ; 200 \mathrm{pM}$ ), a structural homologue of activin-A (Fig. 6).

Effects of inhibin-A on mitogenesis and steroidogenesis. In contrast to activin-A, the addition of recombinant human inhibin-A at doses of 28-2,800 pM did not effect mitogenesis, basal or gonadotropin-stimulated progesterone secretion, nor aromatase activity. As we reported previously (12), addition of activin-A resulted in an increase in cell number on day 4 of culture. The addition of inhibin-A (28-2,800 pM) to wells containing activin-A $(3,600 \mathrm{pM})$ did not change the mitogenic effects observed with activin-A alone (Fig. 7). Similarly, addition of inhibin-A to wells treated with activin-A did not alter the inhibitory effect on progesterone secretion and aromatase activity seen with activin-A alone.

Immunocytochemistry. In all specimens examined, granulosa cells of primary and secondary ovarian follicles located near the surface of the ovary immunostained for activin-A (Fig. $8 \mathrm{~A}$ ). Staining was limited to the granulosa cell cytoplasm and was granular in appearance. Activin-A also was present in granulosa cells and cumulus cells of tertiary preovulatory follicles (Fig. $8 B, C, D$, and $E$ ). Some large tertiary follicles had weak staining in the theca interna layer. Similarly, large luteal cells of the corpus luteum stained positively for activin-A (Fig.

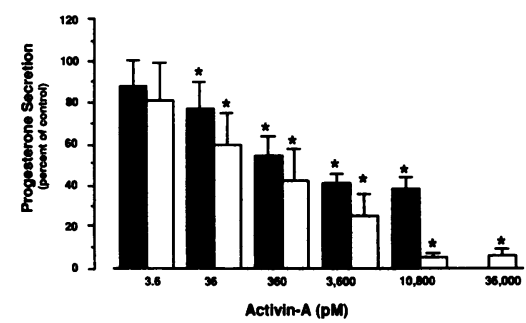

Figure 2. Effect of activin-A on basal progesterone secretion (expressed as percentage of control \pm SEM) by human luteinizing follicular cells on day 2 (black bars) and day 4 (white bars) of culture. Cells were cultured after dispersion in medium M-199 containing $0.1 \%$ human serum albumin and medium was changed after 48 and $96 \mathrm{~h}$.

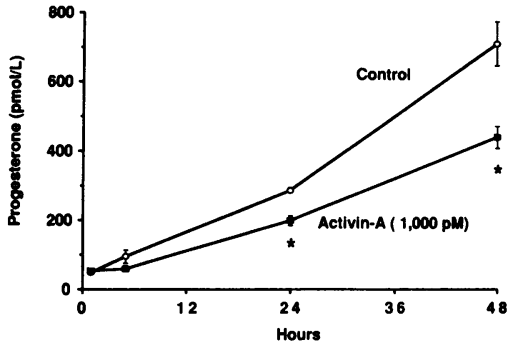

Figure 3. Time course of the suppressive effect of human recombinant activin-A on basal progesterone secretion ( \pm SEM) by human luteinizing follicular cells during the first $48 \mathrm{~h}$ of culture. Cells were cultured after dispersion in medium M-199 containing $0.1 \%$ human serum albumin and medium was changed after 48 and $96 \mathrm{~h}$.

$8 F$ ). No positive staining was observed in the interstitial tissue or in the theca externa layer of the follicles.

Dispersed human ovarian follicular cells stained positively for the activin-A dimer (Fig. $9 \mathrm{~A}$ ). After treatment with 8-BrcAMP, cytoplasmic retraction and development of cellular pseudopods were observed (Fig. $9 \mathrm{~B}$ ). Cells stimulated with 8-Br-cAMP ( $1 \mathrm{mM})$ showed a marked increase in staining intensity for the immunoactive activin-A dimer (Fig. 9 B). Staining intensity of the cells was augmented to a lesser degree by hCG (600 IU/liter) and hFSH (600 IU/liter) but not by inhibin $(2,800 \mathrm{pM})$, activin-A (4,000 pM), and a phorbol ester analogue (phorbol 12-myristate 13-acetate) (10 pM) (data not shown).

\section{Discussion}

Our study demonstrates that recombinant human activin-A, but not recombinant human inhibin-A, can modulate steroidogenesis and mitogenesis in dispersed cultured human luteinizing ovarian follicular cells. Activin-A decreased basal and gonadotropin-stimulated progesterone secretion and aromatase activity in a dose- and time-dependent manner (Figs. 2-6). In contrast to these effects of activin-A on steroidogenesis, TGF-

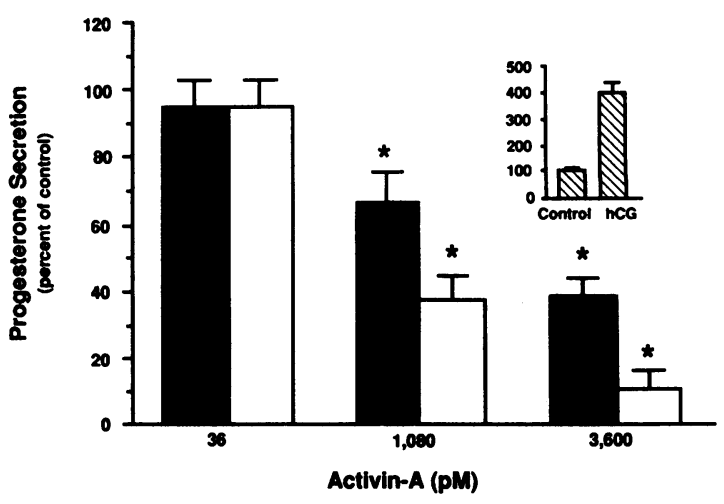

Figure 4. Dose-dependent effects of activin-A on hCG-stimulated progesterone secretion (expressed as percentage of controls \pm SEM) by human luteinizing follicular cells on day 2 (black bars) and day 4 (white bars) of culture. The insert shows the relative increase in hCG-stimulated (600 IU/liter) progesterone secretion versus unstimulated control. Cells were cultured after dispersion in medium M-199 containing $0.1 \%$ human serum albumin and medium was changed after 48 and $96 \mathrm{~h}$. 


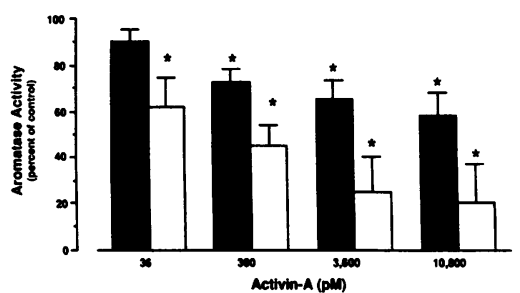

Figure 5. Effect of activin-A on basal aromatase activity (expressed as percentage of control \pm SEM) by human luteinizing follicular cells on day 2 (black bars) and day 4 (white bars) of culture. Cells

were cultured after dispersion in medium M-199 containing $0.1 \%$ human serum albumin and $10^{-6} \mathrm{M}$ androstenedione. Medium was changed after 48 and $96 \mathrm{~h}$ and assayed for 17- $\beta$-estradiol.

$\beta$, a structural homologue of activin-A, increased FSH-stimulated aromatase activity. We did not observe any effects of inhibin-A on basal or gonadotropin-stimulated progesterone secretion and aromatase activity, or on proliferation of human luteinizing follicular cells.

In this study, we also demonstrated that immunoreactive activin-A dimer is present in follicular cells and in the corpus luteum of the human ovary. In our immunocytochemical studies, we used a monoclonal primary antibody that preferentially binds to activin-A but not to activin-B or inhibin. Immunopositive staining for dimeric activin-A was detected in granulosa cells of primary and secondary follicles as well as in granulosa and cumulus cells of large preovulatory follicles. In addition, the activin-A dimer was found in granulosa-lutein but not theca-interstitial cells of the human corpus luteum. Although inhibin/activin subunits and their mRNAs have been demonstrated in ovarian follicular cells of several species, different cellular localizations of these subunits have been described $(15$, $18,19,25-28)$. Despite a few reports to the contrary, the $\beta A$ subunit mRNA, and therefore the potential for production of activin-A dimer, was present in large preovulatory follicles of rat $(18,26,29)$, ovine $(27)$, bovine $(19,27)$, and monkey ovaries (28), and in corpora lutea of monkey (28) and human (15) ovaries. Since the mere presence of either the $\beta A$-subunit or its mRNA provides no information on whether activin-A dimer in the human ovary is present in these cells, our results are the first to indicate that follicular granulosa and corpus luteum cells actually contain immunoreactive activin-A.

Our data further indicate that the accumulation of the activin dimer in dispersed cultured human luteinizing follicular cells is modulated by gonadotropins and their cellular second

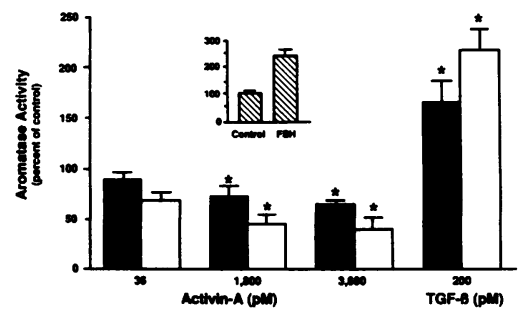

Figure 6. Dose-dependent effects of activin-A on FSH-stimulated aromatase activity (expressed as percentage of control \pm SEM) by human luteinizing follicular cells on day 2 (black bars)and day 4 (white bars) of culture. The insert shows the relative increase in FSH-stimulated (600 IU/liter) aromatase activity versus unstimulated controls on day 4 of culture. Cells were cultured after dispersion in medium M-199 containing $0.1 \%$ human serum albumin and $10^{-6} \mathrm{M}$ androsteneidione. Medium was changed after 48 and $96 \mathrm{~h}$ and assayed for 17- $\beta$-estradiol.

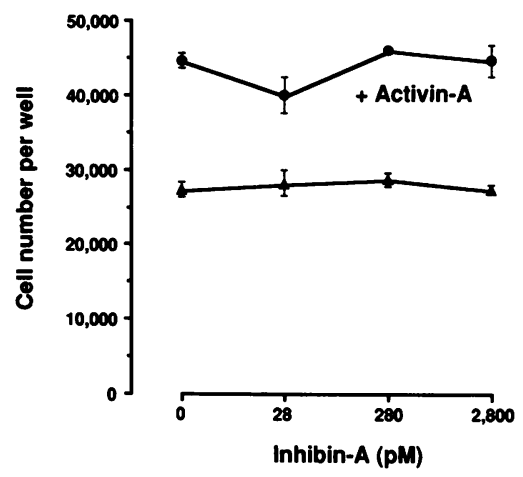

Figure 7. Effects of inhibin-A alone and in combination with activin-A on proliferation (expressed as cell number per well) of human luteinizing follicular cells in culture. The culture medium for proliferation experiments consisted of medium M-199 containing $10 \%$ fetal calf serum. Cells were counted by Coulter Counter (Coulter Corp.) on day 5 of culture.

messenger, cAMP. Addition of cAMP increased the degree for immunopositive staining for activin-A in these cells, while the stimulatory effects after addition of the two gonadotropins increase in vitro and in vivo accumulation of inhibin/activin subunits and their mRNAs, as well as the secretion of immunoreactive and bioactive inhibin- $\alpha$ in the rat, sheep, and human $(9,16-18,30,31)$. Thus, ovarian production of activin and inhibin during the menstrual cycle may be regulated by gonadotropins. We did not observe differences in immunostaining after stimulation of the cells with activin-A, inhibin-A, or a phorbol ester analogue (phorbol 12-myristate 13-acetate).

Two lines of evidence suggest that activin may play a role in regulation of differentiated function and growth of the ovary. First, specific activin binding sites on rat granulosa cells were reported by two laboratories $(9,32)$. The activin binding sites had affinity constants of 1.4 and $3.4 \times 10^{-10}$, respectively $(9$, 32 ) with an estimated receptor content of 4,000 binding sites per cell. Neither TGF- $\beta$ nor inhibin displaced activin from its receptor. These binding data correlate well with the effective dose range of activin which we found in human cells and which others have found in rat and bovine cells $(6,8,11,12,33)$. Since activin acts on pituitary cells at somewhat lower concentrations, these results suggest a lower sensitivity of ovarian versus pituitary cells to activin. The ovary seems to be one of the principal sources of activin and intraovarian activin concentrations may be higher than in the circulation. The lower sensitivity to activin therefore may be necessary for its intragonadal action.

Second, activin-A modulates steroidogenesis and proliferation of ovarian cells in vitro $(4-6,8,12,34)$ and in vivo (10). It seems that the effects of activin on steroidogenesis in ovarian follicular cells depend on cells that are derived from immature follicles or from large preovulatory, mature follicles. Activin-A augments progesterone secretion and FSH-stimulated aromatase activity and induces FSH and luteinizing hormone receptors in undifferentiated granulosa cells from ovaries of immature rats $(4-6,8)$. In contrast to these observations and consonant with the results of our study, activin-A inhibits progesterone secretion and prevents the spontaneous luteinization of granulosa cells from large preovulatory bovine follicles (11). Thus, activin-A may augment or inhibit steroidogenesis in follicular cells depending upon their states of differentiation and maturation. In addition, activin-A can either stimulate or inhibit mitogenesis in cells obtained from steroidogenically ac- 

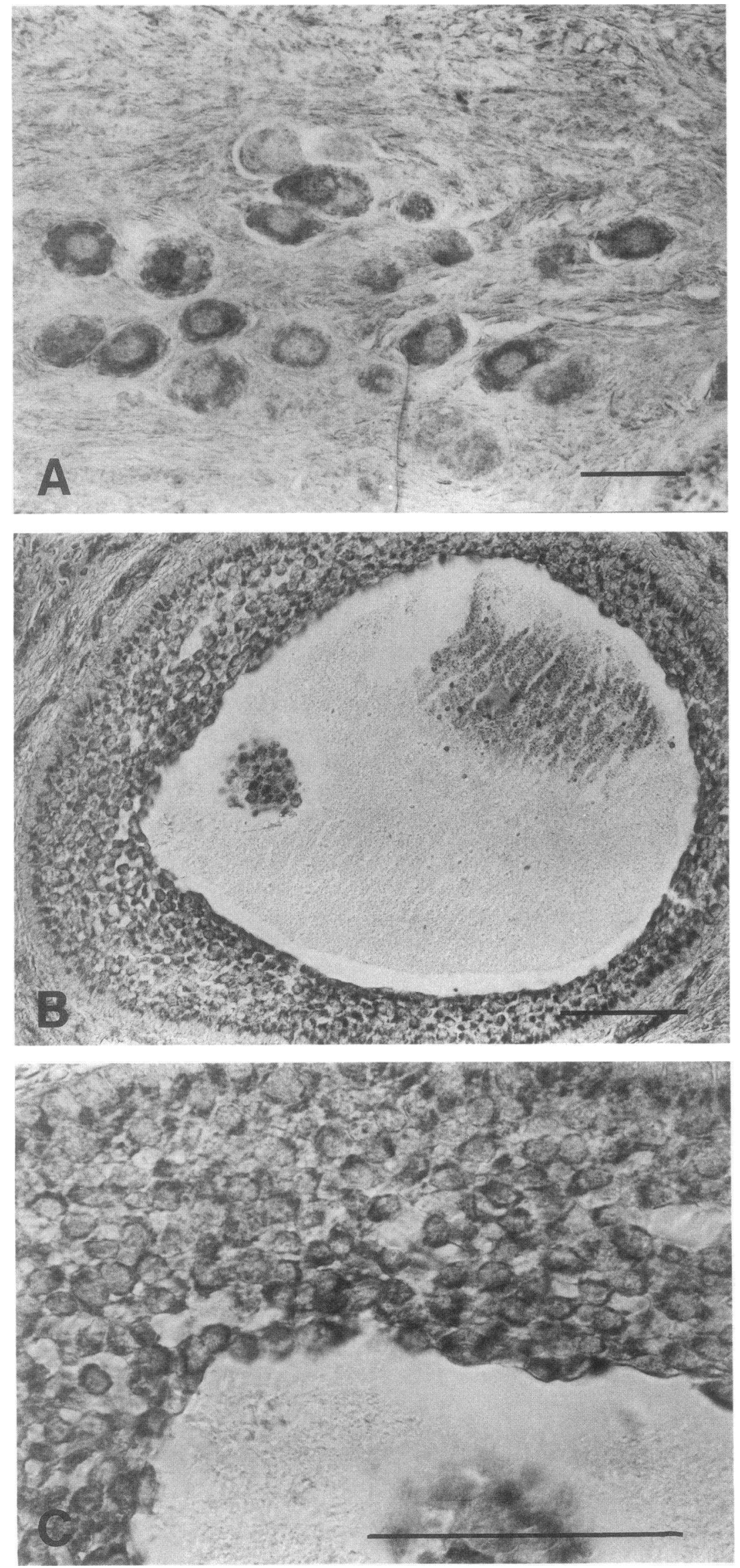

Figure 8. Immunohistochemical localization of activin-A dimer in the human ovary. $(A)$ Granulosa cells of small follicles immunostained for activin-A dimer, while ova are immunonegative. (B) Granulosa cells of a tertiary follicle immunostained for activin-A dimer. Note the group of cumulus cells and the theca interna cells that also stain positively. $(C)$ Detail of $(B)$. Perikaryal cytoplasmic staining is especially prominent in adluminal cells. $(D)$ Adjacent section of the follicle shown in $(B)$ after solid phase-adsorbed activin-A antibody is substituted for the primary antiserum in the procedure. $(E)$ A developing tertiary follicle stained for activin-A dimer. Note the large nucleus of the oocyte surrounded by unstained cytoplasm and the zona pellucida. $(F)$ Granulosa-lutein cells of the human corpus luteum immunostain for activin-A dimer throughout their cytoplasm, while nuclei remain unstained (bar $=50 \mu \mathrm{m})$. 

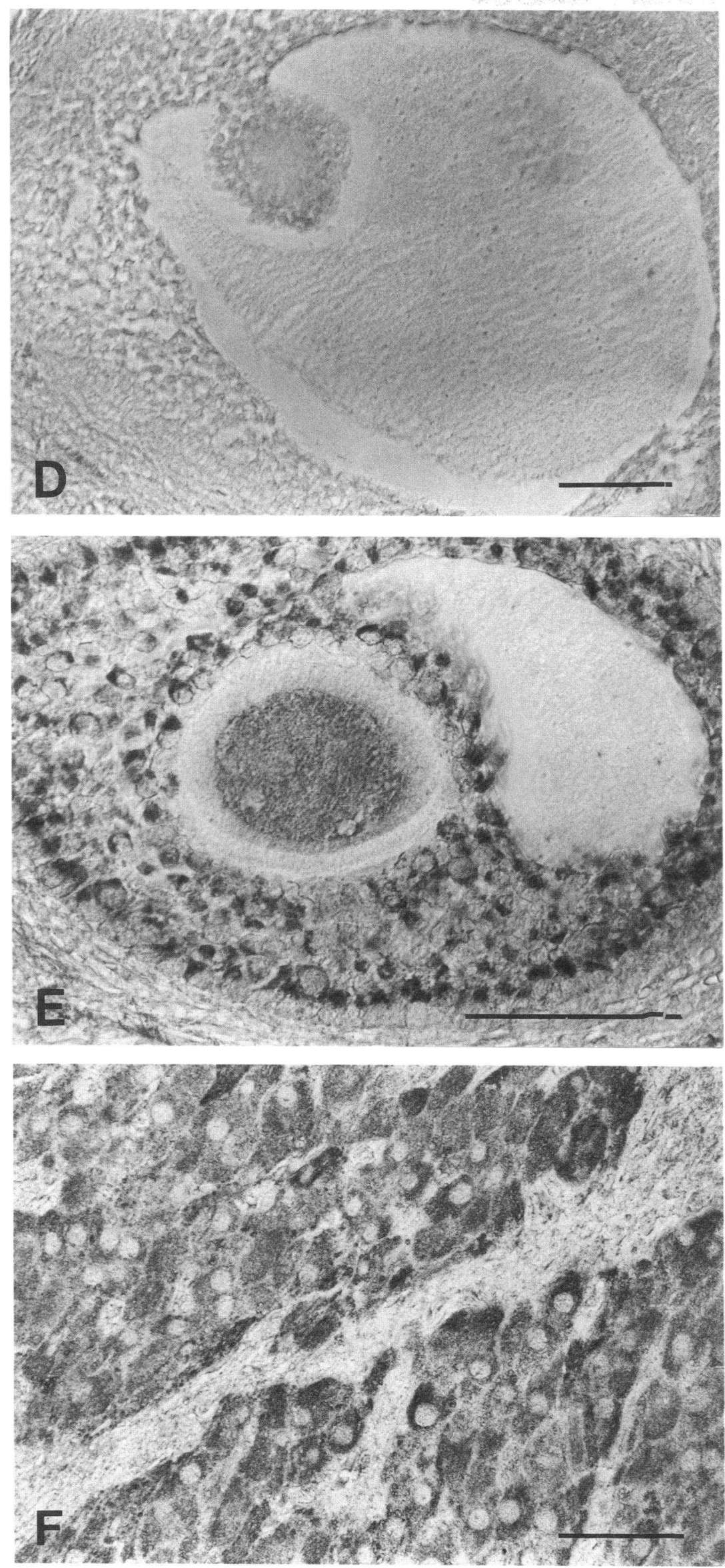

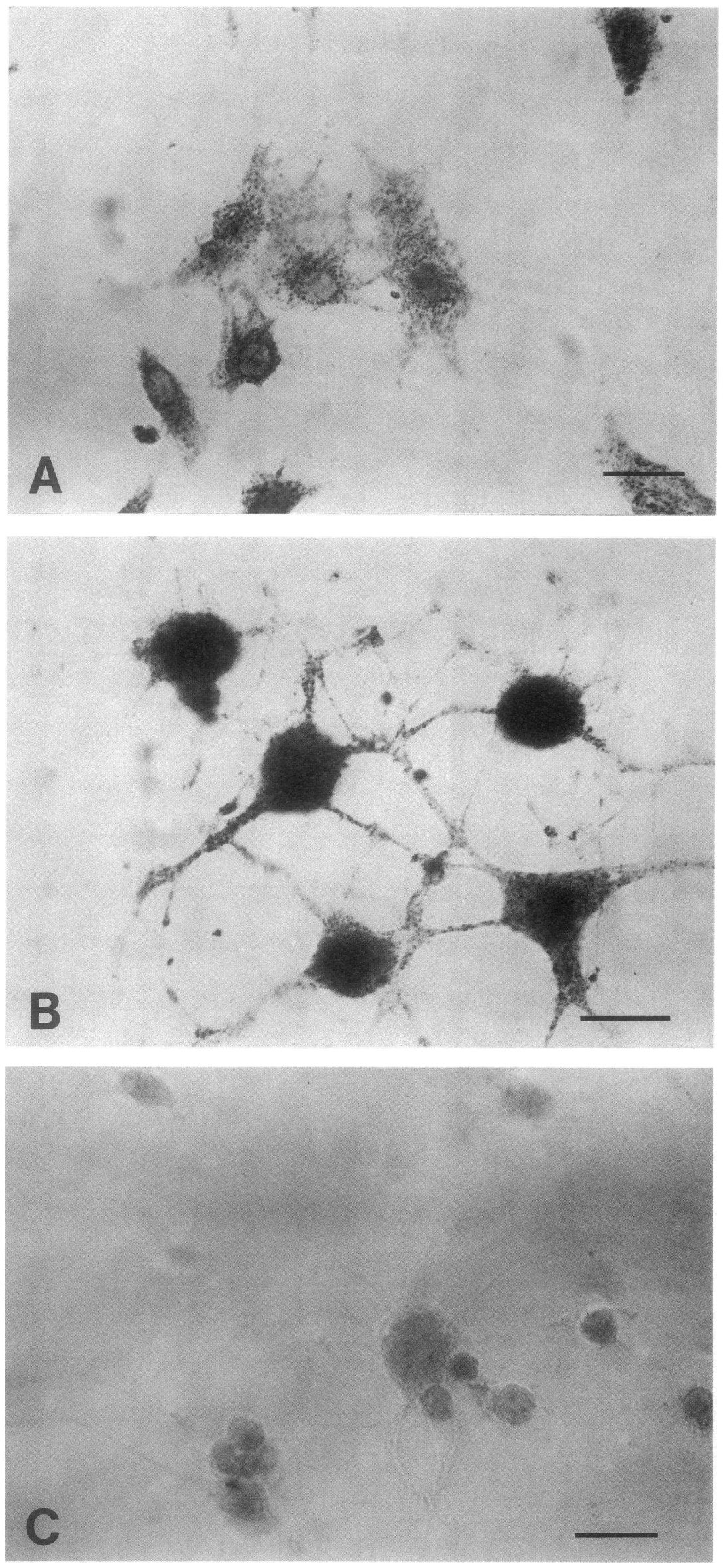

Figure 9. Immunóhistochemical staining for activin-A dimer in cultured human luteinizing follicular cells. $(A)$ Granular cytoplasmic staining for activin-A in unstimulated human ovarian cells. (B) Cytoplasmic staining for activin-A is markedly increased after stimulation in human ovarian cells stimulated with 8-Br-cAMP $(1 \mathrm{mM}) .(C)$ Unstimulated cells fail to stain when solid phase-adsorbed activin-A antibody is substituted for the primary antiserum in the procedure $($ bar $=20 \mu \mathrm{m})$. 
tive organs $(10,12,34,35)$. Based on all of these studies, it seems that activin-A, like its structural homologue TGF- $\beta$, can act as either a positive or a negative modulator of steroidogenesis and growth depending upon the differentiated state of the cells.

The role of inhibin as an autocrine regulator of granulosa cell function has remained controversial. While some investigators have reported inhibitory effects of inhibin on FSHstimulated estrogen production in granulosa cells (36), others have not been able to confirm these results $(5,8)$. We have observed no effects of inhibin-A on basal or gonadotropin-induced granulosa cell steroidogenesis or mitogenesis. Furthermore, inhibin-A did not modulate the effects seen with activinA alone. Thus, it appears that inhibin-A does not exert specific effects on luteinizing human ovarian follicular cells under these experiments conditions. However, these cells secrete immunoreactive inhibin in response to gonadotropins $(31,37)$. Therefore, cellular secretion of high levels of inhibin could lead to saturation of inhibin receptors so that addition of exogenous inhibin might not elicit any additional response.

In conclusion, we have shown that activin-A modulates steroidogenesis and mitogenesis in human luteinized follicular granulosa-luteal cells in vitro. Furthermore, immunoreactive activin-A dimer is present in follicular granulosa cells and corpus luteum cells of human ovaries, and its presence in cultured human follicular cells is regulated by 8-Br-cAMP. As activin-A is present in human ovarian follicular and corpus luteum cells and as it regulates steroidogenesis and mitogenesis of human ovarian luteinizing cells in vitro, it fulfills the classical requirements for a local autocrine/paracrine regulator (38). Therefore, we suggest that activin-A acts as a local modulator of ovarian follicular function in the human ovary.

\section{Acknowledgments}

We thank Dr. L. Bald and B. Fendly (Genentech, Inc.) for providing human recombinant activin and inhibin, and the monoclonal intact activin-A antibody; we thank $\mathrm{C}$. Padula and C. Voytek for their expert technical assistance with the experiments and in the preparation of this manuscript. We are grateful to Mary C. Martin, M. D., Pramila Dandekar, M.Sc., and the staff of the In Vitro Fertilization Program at the University of California, San Francisco, for their continuous support and help in obtaining the cells needed for these studies.

This work was supported in part by National Institutes of Health grant HD-18726; Program Project grant HD-11979; Fogarty Fellowship TW04258-01 to J. Rabinovici; and National Institutes of Health training grant HD-07466-01 to S. J. Spencer.

\section{References}

1. Rabinovici, J., and R. B. Jaffe. 1990. Development and regulation of growth and differentiated function in human and subhuman primate fetal gonads. Endocr. Rev. 11:535-557.

2. Tonetta, S. A., and G. S. diZerega. 1989. Intragonadal regulation of follicular maturation. Endocr. Rev. 10:205-229.

3. Vale, W., C. Rivier, A. Hsueh, C. Campen, H. Meunier, T. Bicsak, J. Vaughan, A. Corrigan, W. Bardin, P. Sawchenko, et al. 1988. Chemical and biological characterization of the inhibin family of protein hormones. Recen Prog. Horm. Res. 44:1-34.

4. Hasegawa, Y., K. Miyamoto, S. Iwamura, and M. Igarashi. 1988. Changes in serum concentrations of inhibin in cyclic pigs. J. Endocrinol. 118:211-219.

5. Hutchinson, L. A., J. K. Findlay, F. L. de Vos, and D. M. Robertson. 1987.
Effects of bovine inhibin, transforming growth factor-beta and bovine activin- $A$ on granulosa cell differentiation. Biochem. Biophys. Res. Commun. 146:14051412.

6. Xiao, S., J. K. Findlay, and D. M. Robertson. 1990. The effect of bovine activin and follicle-stimulating hormone (FSH) suppressing protein/follistatin on FSH-induced differentiation of rat granulosa cells in vitro. Mol. Cell. Endocrinol. 69:1-8.

7. O, W.-S., D. M. Robertson, and D. M. de Kretzer. 1989. Inhibin as an oocyte meiotic inhibitor. Mol. Cell. Endocrinol. 62:307-311.

8. Sugino, H., T. Nakamura, Y. Hasegawa, K. Miyamoto, Y. Abe, M. Igarashi, Y. Eto, H. Shibai, and K. Titani. 1988. Erythroid differentiation factor can modulate follicular granulosa cell functions. Biochem. Biophys. Res. Commun. 153:281-288.

9. LaPolt, P. S., D. Soto, J.-G. Su, C. A. Campen, J. Vaughan, W. Vale, and A. J. Hsueh. 1989. Activin stimulation of inhibin secretion and messenger RNA levels in cultured granulosa cells. Mol. Endocrinol. 3:1666-1673.

10. Woodruff, T. K., R. J. Lyon, S. E. Hansen, G. C. Rice, and J. P. Mather. 1990. Inhibin and activin locally regulate rat ovarian folliculogenesis. Endocrinology. 127:3196-3205.

11. Shukovski, L., and J. K. Findlay. 1990. Activin-A inhibits oxytocin and progesterone production by preovulatory bovine granulosa cells in vitro. Endocrinology. 126:2222-2224.

12. Rabinovici, J., S. J. Spencer, and R. B. Jaffe. 1990. Recombinant human activin-A promotes proliferation of human luteinized preovulatory granulosa cells in vitro. J. Clin. Endocrinol. \& Metab. 71:1396-1398.

13. Schwall, R., A. J. Mason, J. Wilcox, S. Bassett, and A. Zeleznick. 1990. Localization of inhibin/activin subunit mRNAs within the primate ovary. Mol. Endocrinol. 4:75-79.

14. Mayo, K. E., G. M. Cerelli, J. Spiess, J. Rivier, M. G. Rosenfeld, R. M. Evans, and W. Vale. 1986. Inhibin A-subunit cDNAs from porcine ovary and human placenta. Proc. Natl. Acad. Sci. USA. 83:5849-5853.

15. Davis, S. R., Z. Krozowski, R. I. McLachlan, and H. G. Burger. 1987. Inhibin gene expression in the human corpus luteum. J. Endocrinol. 115:R2123.

16. Tsonis, C. G., A. S. McNeilly, and D. T. Baird. 1988. Inhibin secretion by the sheep ovary during the luteal and follicular phases of the oestrous cycle and following stimulation with FSH. J. Endocrinol. 117:283-291.

17. Tsonis, C. G., I. E. Messinis, A. A. Templeton, A. S. McNeilly, and D. T. Baird. 1988. Gonadotropic stimulation of inhibin secretion by the human ovary during the follicular and early luteal phase of the cycle. J. Clin. Endocrinol. \& Metab. 66:915-921.

18. Woodruff, T. K., J. D'Agostino, N. B. Schwartz, and K. E. Mayo. 1988. Dynamic changes in inhibin messenger RNAs in rat ovarian follicles during the reproductive cycle. Science (Wash. DC). 239:1296-1299.

19. Torney, A., Y. Hodgson, R. Forage, and D. de Kretser. 1989. Cellular localization of inhibin mRNA in the bovine ovary by in-situ hybridization. $J$. Reprod. Fertil. 86:391-399.

20. Laherty, R. F., D. Rotten, M. Yamamoto, and R. B. Jaffe. 1985. Effects of oestradiol and prolactin on progesterone production by rhesus monkey luteal cells in vivo. Acta Endocrinol. 108-266.

21. Fluker, M. R., L. A. Marshall, R. B. Jaffe, and S. E. Monroe. 1991. Variable ovarian response to GnRH antagonist-induced gonadotropin deprivation during different phases of the menstrual cycle. J. Clin. Endocrinol. \& Metab. 72:912-919.

22. Marshall, L. A., M. R. Fluker, R. B. Jaffe, and S. E. Monroe. 1991. Inhibition of follicular development by a potent antagonistic analog of gonadotropin releasing hormone (detirelix). J. Clin. Endocrinol. \& Metab. 72:927-933.

23. Lucas, C., L. N. Bald, B. M. Fendly, M. Mora-Worms, E. J. Patzer, and M. A. Palladino. 1990. The autocrine production of transforming growth factor$\beta 1$ during lymphocyte activation: a study with a monoclonal antibody-based ELISA. J. Immunol. 145:1415-1422.

24. Schwall, R., K. Nikolics, E. Szonyi, C. Gorman, and A. Mason. 1988. Recombinant expression and characterization of human activin A. Mol. Endocrinol. 2:1237-1242.

25. Davis, S. R., F. Dench, I. Nikolaidis, J. A. Clements, R. G. Forage, Z. Krozowski, and H. G. Burger. 1986. Inhibin A-subunit gene expression in the ovaries of immature female rats is stimulated by pregnant mare serum gonadotrophin. Biochem. Biophys. Res. Commun. 138:1191-1195.

26. Meunier, H., S. B. Cajander, V. J. Roberts, C. Rivier, P. E. Sawchenko, A. J. Hsueh, and W. Vale. 1988. Rapid changes in the expression of inhibin alpha-, beta A-, and beta B-subunits in ovarian cell types during the rat estrous cycle. Mol. Endocrinol. 2:1352-1363.

27. Rodgers, R. J., S. J. Stuchbery, and J. K. Findlay. 1989. Inhibin mRNAs in ovine and bovine ovarian follicles and corpora lutea throughout the estrous cycle and gestation. Mol. Cell. Endocrinol. 62:95-101.

28. Schwall, R. H., A. J. Mason, J. N. Wilcox, S. G. Bassett, and A. J. Zeleznik. 1990. Localization of inhibin/activin subunit mRNAs within the primate ovary. Mol. Endocrinol. 4:75-79. 
29. Penschow, J. D., G. P. Aldred, P. A. Darling, J. Haralambidis, V. E. Hammond, L. B. van Leeuwen, A. J. Mason, H. D. Niall, P. Seeburg, and J. P. Coghlan. 1990. Differential expression of inhibin alpha and beta A subunit genes in rat and mouse ovarian follicles during pregnancy. J. Mol. Endocrinol. 4:247255.

30. Meunier, H., C. Rivier, A. J. W. Hsueh, and W. Vale. 1988. Distribution and regulation of inhibin subunit mRNAs. In Non-steroidal Gonadal Factors: Physiological roles and Possibilities in Contraceptive Development. G. D. Hodgen and Z. Rosenwaks, editors. Jones Institute Press, Norfolk, VA. 47-52.

31. Tsonis, C. G., S. G. Hillier, and D. T. Baird. 1987. Production of inhibin bioactivity by human granulosa-lutein cells: stimulation by $\mathrm{LH}$ and testosterone in vitro. J. Endocrinol. 112:R11-14.

32. Sugino, H., T. Nakamura, Y. Hasegawa, K. Miyamoto, M. Igarashi, Y. Eto, H. Shibai, and K. Titani. 1988. Identification of a specific receptor for erythroid differentiation factor on follicular granulosa cell. J. Biol. Chem 263:15249-15252.

33. Hasegawa, Y., K. Miyamoto, Y. Abe, T. Nakamura, H. Sugino, Y. Eto, H. Shibai, and M. Igarashi. 1988. Induction of follicle stimulating hormone receptor by erythroid differentiation factor on rat granulosa cell. Biochem. Biophys. Res. Commun. 156:668-674.

34. Gonzalez-Manchon, C., and W. Vale. 1989. Activin-A, inhibin and transforming growth factor-beta modulate growth of two gonadal cell lines. Endocrinology. 125:1666-1672.

35. Spencer, S. J., J. Rabinovici, and R. B. Jaffe. 1990. Human recombinant activin-A inhibits proliferation of human fetal adrenal cells in vitro. J. Clin Endocrinol. \& Metab. 71:1678-1680.

36. Ying, S. Y., A. Becker, N. Ling, N. Ueno, and R. Guillemin. 1986. Inhibin and beta type transforming growth factor (TGF beta) have opposite modulating effects on the follicle stimulating hormone (FSH)-induced aromatase activity of cultured rat granulosa cells. Biochem. Biophys. Res. Commun. 136:969-975.

37. Demoulin, A., A. Guichard, T. M. Mignot, L. Cedard, R. Lambotte, and P. Franchimont. 1986. Inhibin concentration in the culture media of human oocyte-cumulus-corona cell complexes is not related to subsequent embryo cleavage. Fertil. Steril. 46:1150-1152.

38. Franchimont, P. 1986. Paracrine control. In Clinics in Endocrinology and Metabolism. P. Franchimont, editor. W. B. Saunders Co., Ltd., London. ix-xiii. 